J. Clin. Chem. Clin. Biochem.

Vol. 15, 1977, pp. 21-26

\title{
A New Marker for Neuraminidase-Treated Human Serum Glycoproteins from the Haemolymph of Tridacna maxima (Röding)'1)
}

\author{
By G. Uhlenbruck, G. Steinhausen
}

Department of Immunobiology, Medical University Clinic Cologne

and H. G Schwick

Behringwerke Marburg

(Eingegangen am 15. Juli/1. November 1976)

Summary: Highly purified human serum glycoproteins were treated with neuraminidase. The exposed subterminal carbohydrate structures reacted strongly with an anti-galactan precipitin from the haemolymph of Tridacna maxima which detects terminal, non-reducing $\beta$ - $D$-galactoside residues. This invertebrate precipitin, Tridacnin, may be used as a marker for nearly two thirds of all asialo serum glycoproteins. A number of different cross-reactions with various other polysaccharides and galactans subdivides those neuraminidase-treated glycoproteins into several subgroups, indicating that the uncovered carbohydrate structures are not always completely identical. In this way, together with the cross-reacting precipitins from plant and invertebrate origin, Tridacnin may be a useful tool for elucidating and establishing the structure of the carbohydrate part of serum glycoproteins.

\section{Ein neuer Marker für mit Neuraminidase behandelte Serum-Glykoproteine des Menschen aus der Hämolymphe von Tridacna maxima (Röding)}

Zusammenfassung: Hochgereinigte menschliche Serum-Glykoproteine wurden mit Neuraminidase behandelt. Die dabei freigelegten subterminalen Kohlenhydratstrukturen reagierten stark mit einem Anti-Galactan Präzipitin aus der Hämolymphe von Tridacna maxima, welches endständige, nicht-reduzierend gebundene $\beta$-D-Galactosido-Reste erfaßt. Dieses Präzipitin aus Invertebraten, Tridacnin, kann als Marker für nahezu zwei Drittel aller Asialo-Serum-Glykoproteine benutzt werden. Eine ganze Reihe verschiedener Kreuzreaktionen mit einigen anderen Polysacchariden und Galactanen unterteilt diese Neuraminidase-behandelten Glykoproteine wiederum in mehrere Untergruppen, was darauf hinweist, daß die freigelegten Kohlenhydratgruppierungen nicht alle vollständig identisch untereinander sind. In dieșer Hinsicht kann Tridacnin, zusammen mit kreuzreagierenden Präzipitinen von Pflanzen und Invertebraten, als ausgezeichnetes Reagenz benutzt werden, um die Struktur der Kohlenhydratanteile von Serum-Glykoproteinen aufzuklären.

\section{Introduction}

During the last decade our work has been mainly concerned with the chemical structure and the serological reactions of the carbohydrate groups from different cell membrane glycosubstances, which are uncovered or de novo serologically available after neuraminidase treatment: $\alpha$-linked $\mathrm{N}$-acetyl- $D$-galactosamine (the socalled Helix pomatia (HP)-receptor), $\beta$-D-galactosyl(1-3)-N-acetyl- $D$-galactosamine (the so-called ThomsenFriedenreich or $\mathrm{T}_{\mathrm{F}}$ receptor) and $\mathrm{N}$-acetyl-lactosamine

\footnotetext{
1) This work has been supported by the Deutsche Forschungsgemeinschaft.
}

(the pneumococcus Type XIV cross-reacting receptor). This work has been summarized in a recent review (1).

Subsequently, identical terminal carbohydrate structures have been found in soluble glycosubstances like submaxillary gland mucin (HP) (2), in the anti-freeze glycoprotein $\left(\mathrm{T}_{\mathrm{F}}\right)(3)$ and in human serum glycoproteins (XIV) (4) of the N-acetyl-lactosamine type (5). The fact that $\beta$-galactoside structures, linked 1-4 (or 1-6?) glycosidically to $\mathrm{N}$-acetyl-D-glucosamine do occur (5) in most human serum glycoproteins after neuraminidase treatment prompted us to investigate the reaction of Tridacnin (6), a potent anti- $\beta$-( $1-6$ or $1-4)$-galactoside precipitin (it was named anti-galactan because of its reaction with galactan polysaccharides) with neuraminidase-treated serum glycoproteins (4). 
The results of our investigations show that Tridacnin indeed gives a strong precipitin reaction with most of the neuraminidase-treated serum glycoproteins and may be useful as a novel tool in research or clinical diagnosis (polyagglutinability).

\section{Materials and Methods}

Purified serum glycoproteins: Preparations from the Behringwerke Marburg.

Tridacnin: A purified sample from the haemolymph of Tridacna maxima was used (6). IgA mouse myeloma protein from ascites fluid was kindly supplied by Dr. Michael Potter (7).

Galactans: Galactans of various origins were used and have also been described and listed in previous papers of this series $(7,8)$.

Agar-gel electrophoresis and gel diffusion were performed in the usual way, as mentioned in earlier papers $(6,7,8,9)$.

Neuraminidase-treatment of glycoprotein samples: Purified glycoproteins were dissolved in Neuraminidase (Behringwerke) to make up a $5 \%$ solution. Incubation time at $37^{\circ} \mathrm{C}$ was $1.5 \mathrm{~h}$. The solution was used in this way for agar-gel diffusion or gel electrophoresis tests.

In a typical experiment, $5 \mathrm{mg}$ of the glycoprotein was dissolved in $0.1 \mathrm{ml}$ neuraminidase, corresponding to 50 units of the enzyme.

\section{Results}

Agar-gel diffusion tests with neuraminidase-treated $(=N)$ serum glycoproteins and Tridacnin

The results of a first experiment can be seen in figure 1 . Note some "non-complete identity" reaction of cholinesterase. Several commercial bovine cell cholinesterases did not react after neuraminidase treatment. Horse serum cholinesterase did, however.

\section{Cross-reactions between serum glycoproteins $(N)$ and galactans}

The picture of this experiment is shown in figure 2. Again, cholinesterase $(\mathrm{N})$ does not give a complete identity line with the Tridacnin-positive polysaccharide from pneumococcus.

Further cross-reactions with other galactans are shown in figure 3 . The fusion between galactans and serum glycoproteins is not always complete (see well 2).

Arother example of these cross-reacting fusion lines between serum glycoproteins $(\mathrm{N})$ and galactans is given

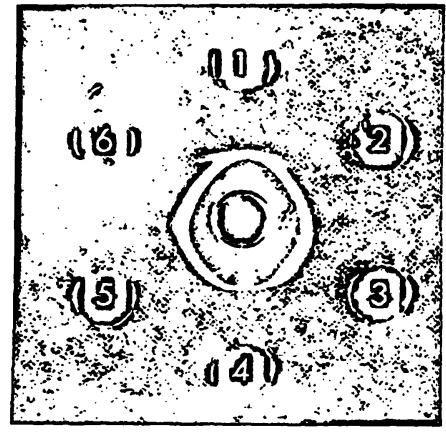

Fig. 1. Agar gel diffusion tests. Centre Tridacnin $1=$ Cholinesterase $(\mathrm{N})$ $2=$ Secretory piece IgA $(\mathrm{N})$ $3=$ Lactoferrin $(\mathrm{N})$ $4=8 \mathrm{~S}-\alpha_{3}$-glycoprotein $(\mathrm{N})$ $5=\beta_{2}$-glycoprotein I $(\mathrm{N})$ $6=$ Haemopexin $(\mathrm{N})$

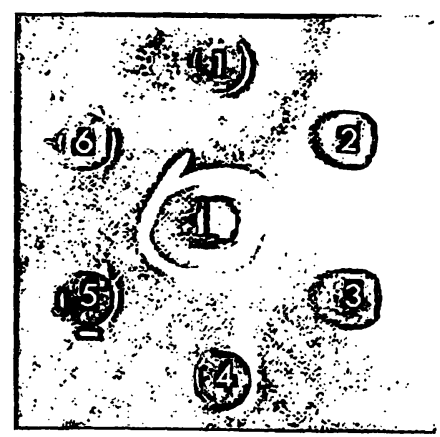

Fig. 4. Agar gel diffusion tests. Centre Tridacnin $1=$ Haemopexin $(\mathrm{N})$ 2 = Arabinogalactan (larch) 3 = Lactoferrin $(\mathrm{N})$ $4=$ Pneumogalactan (bovine) $5=\alpha_{2}$-macroglobulin $(\mathrm{N})$ $6=$ Helix pomatia galactan

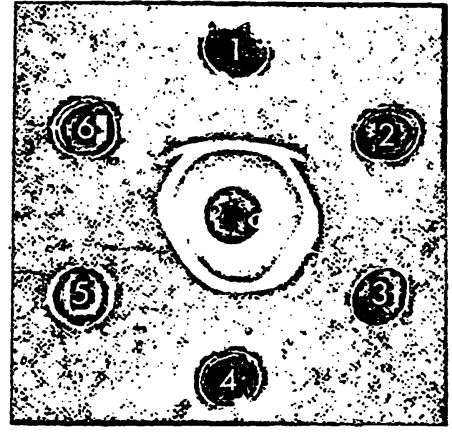

Fig. 2. Agar gel diffusion tests. Centre Tridacnin $1=$ Cholinesterase $(\mathrm{N})$ 2,4,6 = Pneumococcus Type XIV polysaccharide

$3=$ Lactoferrin $(\mathrm{N})$

$5=$ Secretory piece $(\mathbb{N})$

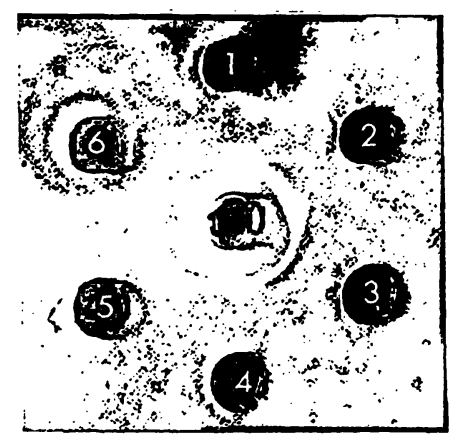

Fig. 5. Agar gel diffusion tests. Centre Tridacnin

1 = Haptoglobin $(\mathrm{N})$

2 = Arabinogalactan (larch)

$3=8 \mathrm{~S}-\alpha_{3}$-glycoprotein $(\mathrm{N})$

$4=$ Pneumogalactan (bovine)

$5=$ Cholinesterase $(N)$

$6=$ Helix pomatia galactan

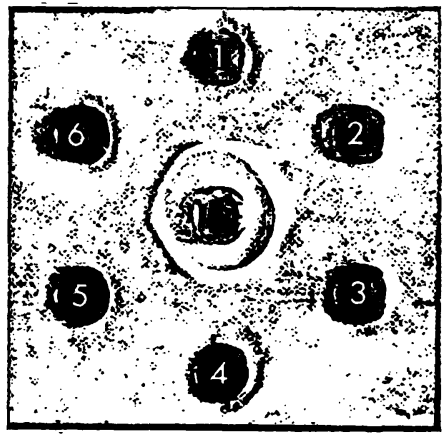

Fig. 3. Agar gel diffusion tests. Centre Tridacnin $1=$ Cholinesterase $(N)$ 2 = Arabinogalactan (larch) $3=\beta_{2}-$ gly coprotein $I(N)$ 4 = Pneumogalactan (bovine) $5=$ Secretory piece $(\mathrm{N})$ $6=$ Helix pomatia galactan 
in figure 4. Here the lines of Haemopexin $(\mathrm{N})$ and Helix pomatia galactan do not fuse completely.

Other fusion lines are demonstrated in figure 5. Here again, Tridacnin precipitates with several galactans and glycoproteins $(\mathbf{N})$, showing in most cases a complete identity reaction, in some, however, not. In these cases slight differences in receptor area must be present.

All these results are summarized in table 1 and 2. Table 1 gives the carbohydrate composition of the glycoproteins which are very strongly precipitated after neuraminidase treatment by Tridacnin. Those serum glycoproteins which only react weakly after neuraminidase treatment with Tridacnin, and those which do not precipitate in agar-gel diffusion are listed in table 2. Table 3 summarizes the different cross-reactions with various galactans. As can be deduced from the Table, six groups can be distinguished. Group I also includes a seminal plasma

Tab. 1. Serum glycoproteins, which precipitate strongly with Tridacnin after they have been treated with neuraminidase. (Analysis according to Heide \& Schwick (10)).

\begin{tabular}{lcclc}
\hline Glycoprotein & Hexoses & $\begin{array}{l}\text { Acetyl- } \\
\text { hexos- } \\
\text { amine }\end{array}$ & $\begin{array}{l}\text { Acetyl- } \\
\text { neura- } \\
\text { minic } \\
\text { acid }\end{array}$ & $\begin{array}{l}\text { Total } \\
\text { carbo- } \\
\text { hydrate }\end{array}$ \\
& {$[\%]$} & {$[\%]$} & {$[\%]$} & {$[\%]$} \\
\hline$\beta_{2}$-glycoprotein I & 7.8 & 6.2 & 4.5 & 18.8 \\
Haemopexin & 6.9 & 7.7 & 6.9 & 21.9 \\
Haptoglobin & 5.6 & 5.3 & 5.3 & 16.4 \\
Serum cholinesterase & 9.3 & 8.4 & 6.0 & 23.9 \\
$\alpha_{2}$-macroglobulin & 3.4 & 3.9 & 1.8 & 9.4 \\
Secretory piece & 7.1 & 4.4 & 1.9 & 15.6 \\
8S- $\alpha_{3}$-glycoprotein & 11.0 & 10.8 & 9.2 & 31.4 \\
Lactoferrin & 2.7 & 2.2 & 0.8 & 6.3 \\
3.1 S $\alpha_{2}$-glycoprotein & - & - & - & - \\
C3-activator & 2.2 & 1.8 & 1.5 & 5.7 \\
$\alpha_{1}$-antichymotrypsin & 9.9 & 7.4 & 6.6 & 24.6 \\
Thyroxine binding & 5.6 & 5.0 & 3.7 & 14.8 \\
globulin & & & & \\
\hline
\end{tabular}

Tab. 2. Serum glycoproteins, which react weakly or not at all with Tridacnin after they had beèn treated with neuraminidase.

Precipitin reaction with Tridacinin of serum glycoproteins after neuraminidase treatment

\begin{tabular}{ll} 
Weak but definite reaction & No reaction \\
\hline Fetuin & $\alpha_{1}$ B-glycoprotein \\
Human colostral IgA & Histidin-rich 3.8 S $\alpha_{2}$-glycoprotein \\
Acid $\alpha_{1}$-glycoprotein & Gc-globulin \\
Antithrombin III & $\alpha_{2}$ HS-glycoprotein \\
C1-Inactivator & Transferrin \\
Inter- $\alpha$-trypsininhibitor & $\beta_{2}$-glycoprotein III \\
& Prothrombin \\
& 9.5 S $\alpha_{1}$-glycoprotein \\
& Coeruloplasmin \\
& Uromucoid \\
& $\alpha_{1}$-antitrypsin \\
\hline
\end{tabular}

glycoprotein, on which we will report in another context (with W. P. Herrmann, unpublished results). The nature of these different cross-reactions is still unknown.

In this connection, it is interesting to note that IgA from human colostrum gives two Tridacnin precipitation lines before treatment with neuraminidase, and only one afterwards. However, genuine IgA reacts in both cases much more weakly than the secretory piece in isolated form. IgA mouse myeloma protein in purified form (7) does not react with Tridacnin after it has been treated with neuraminidase. This myeloma protein is a potent antigalactan itself.

\section{Agar-gel electrophoretic analysis of serum glycoproteins (N) with Tridacnin}

The neuraminidase-treated serum glycoproteins were submitted to agar-gel electrophoresis ("immune"-electrophoresis) and made visible by their precipitin reaction with Tridacnin (trough). The results are given in figures 6,7 and 8 . Before neuraminidase-treatment, there was no visible reaction between Tridacnin and any of these serum glycoproteins. Reactions with other antigalactans $(7,11)$ were also negative.

Tab. 3. Identity reactions, obtained by precipitation (Ouchterlony-technique), between Tridacnin and some polysaccharides and serum glycoproteins.

\begin{tabular}{lllllll}
\hline $\begin{array}{l}\text { Polysaccharide } \\
\text { Bovine pneumo- }\end{array}$ & I & II & III & IV & V & VI \\
galactan & + & + & + & - & + & - \\
$\begin{array}{l}\text { Arabinogalactan } \\
\text { (larch) }\end{array}$ & + & - & - & + & + & + \\
$\begin{array}{l}\text { Helix pomatia } \\
\text { galactan }\end{array}$ & + & + & + & - & - & - \\
$\begin{array}{l}\text { Pneumococcus } \\
\text { Type XIV } \\
\text { polysaccharide }\end{array}$ & + & + & - & - & + & + \\
\hline
\end{tabular}

$+=$ identity reaction

$-=$ non-identity reaction

Group I:

Peptone glycoprotein

Human seminal glycoprotein

$\beta_{2}$-glycoprotein I (N)

Secretory piece $(N)$

Haptoglobin $(\mathrm{N})$

Group II:

$\alpha_{2}$-macroglobulin (N)

Group III:

$8 \mathrm{~S}-\alpha_{3}$-glycoprotein $(\mathrm{N})$

Serum cholinesterase $(\mathrm{N})$
Group IV:

Haemopexin $(\mathrm{N})$

3.1 S $\alpha_{2}$-glycoprotein $(\mathrm{N})$

Thyroxine binding globulin $(\mathrm{N})$

Group V:

C3-activator (N)

Group VI:

$\alpha_{1}$-antichymotrypsin (N) 


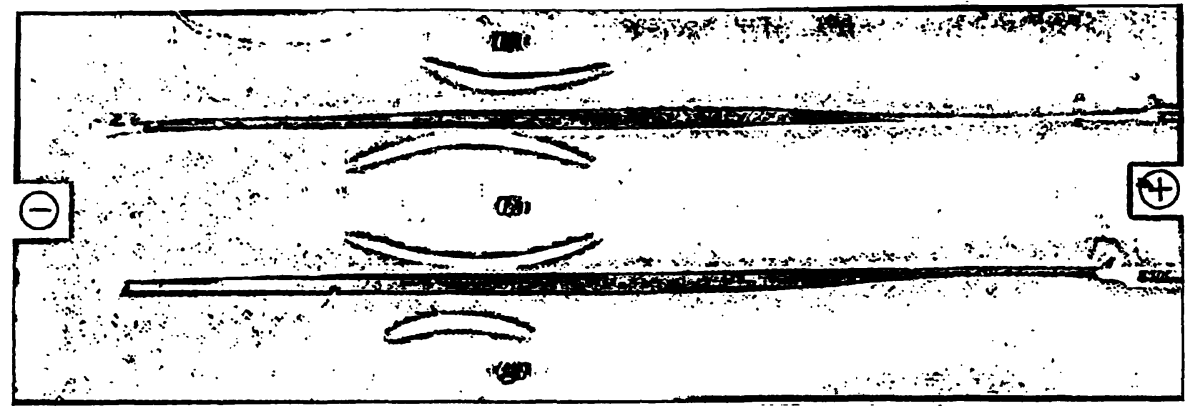

Fig. 6. Agar gel electrophoresis ("Immune" electrophoresis).

Troughs: Tridacnin

Upper well: Cholinesterase $(\mathrm{N})$

Middle well: Secretory piece $(\mathrm{N})$

Lower well: Lactoferrin $(\mathrm{N})$

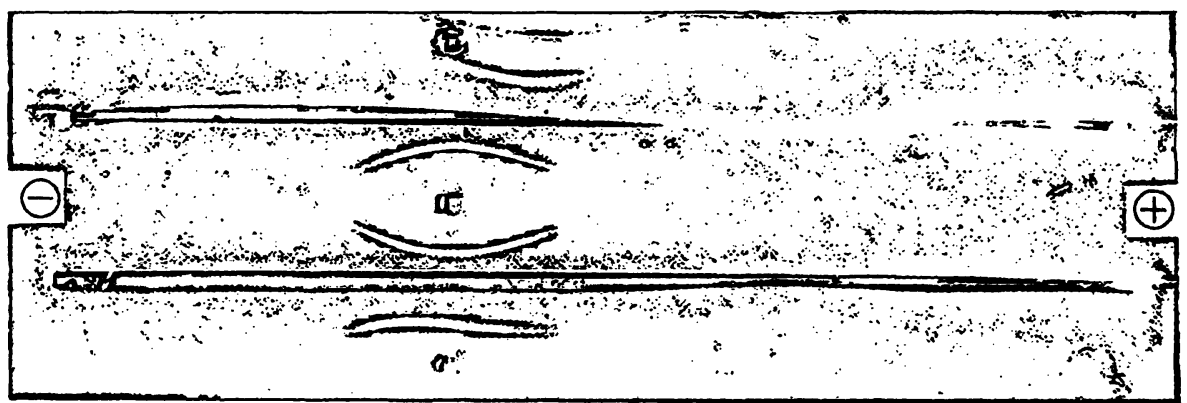

Fig. 7. Agar gel electrophoresis ("Immune" electrophoresis).

Troughs: Tridacnin

Upper well: $\alpha_{2}$-macroglobulin (N)

Middle well: $8 \mathrm{~S}-\alpha_{3}$-glycoprotein (N)

Lower well: Peptone from pig stomach

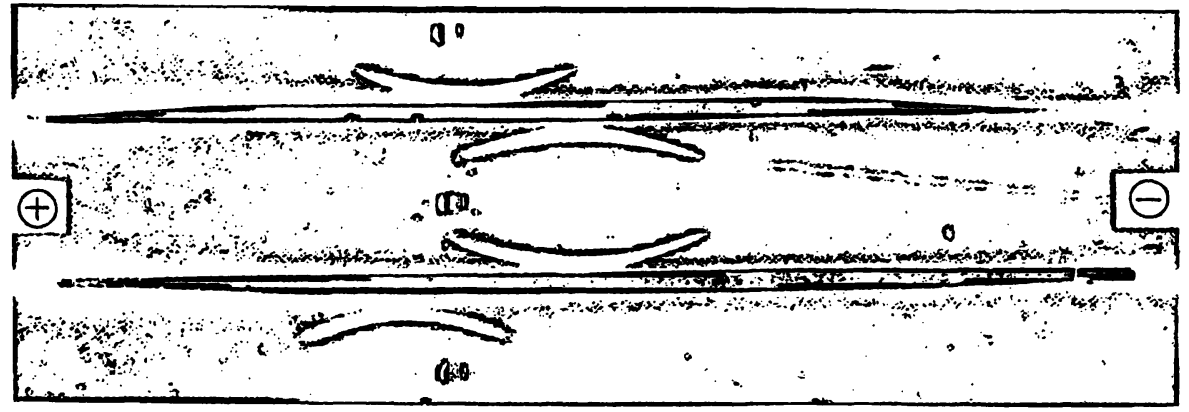

Fig. 8. Agar gel electrophoresis ("Immune" electrophoresis).

Troughs: Tridacnin

Upper well: Haemopexin $(\mathrm{N})$

Middle well: $\beta_{2}$-glycoprotein I (N)

Lower well: Haptoglobin (N)

\section{Discussion}

Tridacnin is a substance in the haemolymph of the elongate bivalve clam Tridacna maxima ((Röding) (8)) which agglutinates erythrocytes and other cells. In addition, it is a strongly precipitating anti-galactan $(6,7)$. Its precipitating and agglutinating properties have been reviewed recently in a monograph (11). It has a molecular weight of about 300 000-500 000 Dalton and can be split by reductive cleavage using 
mercaptoe thanol and subsequent alkylation into subunits of 44000 and 22000 Dalton. The acid substance migrating toward the anode can be precipitated by basic polymers (lysozyme also) and is easily destroyed by certain proteases, for instance polymer-bound pronase $(6,9,11)$.

Tridacnin agglutinates red cells of different species, lymphocytes, thrombocytes, tumour cells and spermatozoa (11). In addition, it precipitates preferably with galactans of different origin, having terminal non reducing $\beta$-(1-6)-digalactobiose structures, with the pneumococcus Type XIV polysaccharide (8) and with a lipopolysaccharide from Salmonella Perth (unpublished results with $O$. Lüderitz).

Tridacnin-reactive material from cell membranes in the form of a glycoprotein has so far only been isolated from bovine red cells (8). Peptone from pig stomach (9), a human seminal plasma glycoprotein and secreted blood group glycoproteins are precipitated directly, without any treatment. Of the galactans, the mite galactan is of particular importance, as it represents the house dust mite allergen (12). The reactions of Tridacnin with various glycosubstances are summarized in Table 4.

The reaction with the neuraminidase-treated serum glycoproteins may be due to the terminal $\beta-(1-4)$ galactosido structures (5). However, not all react and some, for instance fetuin, for which only this terminal structure has been established, precipitate only weakly.

Tab. 4. Glycosubstances which are precipitated by Tridacnin (modified from Uhlenbruck et al. (10)).

I. Glycoproteins

1. genuine:

Peptone from porcine stomach Seminalplasma glycoprotein

Human secreted blood group substances

2. After partial acid hydrolysis:

Bovine red cell mucoid

Secreted blood group glycoproteins

3. After neuraminidase-treatment:

Serum glycoproteins strongly reacting group weakly reacting group

Pig submaxillary mucin

II. Polysaccharides

1. Galactans sensu strictu

a) Snail galactans

b) Galactans from plants and algae

c) Pneumogalactan (bovine)

d) Mite galactan (house dust allergen) and other miccrobiall galactañs

2. Cross-reacting polysaccharides from bacteria:

a) Lipopolysaccharides (Salmonella Perth)

b) Pneumococcus Type XIV polysaccharide

As a hypothesis, we therefore favour the view that in the strongly reacting glycoproteins $(\mathrm{N}) \beta-(1-6)$-galactoside structures may be present too. However, further experiments in this direction must clarify the exact chemical structure of the Tridacnin receptor in various neuraminidase-treated serum glycoproteins. This also holds for the different identity and partial identity reactions with certain galactans.

Nevertheless, as a special marker for neuraminic-acidfree serum glycoproteins, Tridacnin may be most useful. In cases of bacterially caused polyagglutinability, not only the red cells ( $\mathrm{T}_{\mathrm{F}}$ transformation) but also the serum glycoproteins are altered by the bacterial neuraminidase (13). Also of importance is the reaction with the secretory piece, as it may play a role in colon carcinoma. In addition, the fate of serum asialoglycoproteins may be studied. In comparative experiments we found that Tridacnin reacts and precipitates very much better than the anti-N-acetyl-lactosamine-specific anti-pneumococcus Type XIV cross-reacting antiserum from horse (14) hitherto used in blood group research, and also with human blood group substances, especially after partial acid hydrolysis.

But even in this case, the reactions are not identical and comparable with each other (see fig. 9); as with pneumococcus Type XIV polysaccharide (middle), Tridacnin and the horse antiserum do not show identical reactions. This again underlines the difficulty of interpreting the numerous cross-reactions of Tridacnin in immunochemical terms. However, the materials listed in this paper represent a broad spectrum of glycosubstances, which may help to elucidate this mechanism.

In this connection it is worth mentioning that lacto-Nneotetraosyl-ceramide strongly reacts with Tridacnin (unpublished results with Dr. P. Hanfland, Bonn), a fact which supports the additional anti-N-acetyl-lactosamine specificity of this precipitin. On the other hand, quite a number of ( $\beta$ )-galactoside-specific lectins, for instance the one from the roach Rutilus rutilus, precipi-

4. Membraneglycoproteins from:

Erythrocytes Lymphocytes Milk fat globules Spermatozoa Platelets (Tumour cells?)

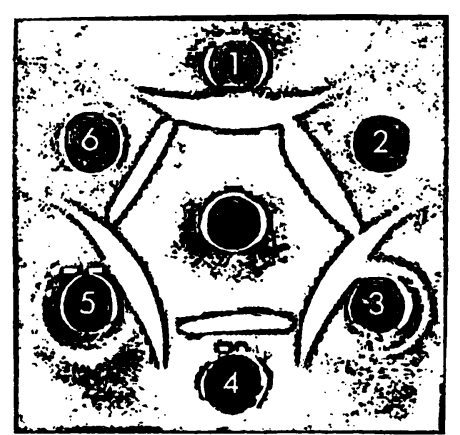

Fig. 9. Agar gel diffusion tests. Centre Pneumococcus Type XIV polysaccharide. $1,3,5=$ Tridacnin 2,4,6 = Pneumococcus Type XIV antiserum from horse 
tate with a characteristic collection of these neuraminidase-treated glycoproteins too (with $\alpha_{2}$-macroglobulin, inter- $\alpha$-trypsin inhibitor, acid $\alpha_{1}$-glycoprotein, uromucoid, $x_{1}$-antichymotrypsin, prothrombin and others) (unpublished results with Dr. V. Hořejši, Prague).

\section{References}

1. Uhlenbruck, G., Dahr, W., Rothe, A. \& Baldo, B. A. (1974), Forschungsberichte des Landes Nordrhein-Westfalen Nr. 2475, Westdeutscher Verlag Opladen.

2. Gottschalk, A., Schauer, H. \& Uhlenbruck, G. (1971), Hoppe-Seyler's Z. Physiol. Chem. 352, 117-124.

3. Glöckner, W. M., Newman, R. A. \& Uhlenbruck, G. (1975), Biochem. Biophys. Res. Commun. 66, 701-705.

4. Uhlenbruck, G., Steinhausen, G. \& Schwick, H. G. (1976), Verhandlungen Deutsche Gesellsch. Bluttransfusion $u$. Immunhämatologie, Frankfurt/Main, in press.

5. Montreuil, J. (1975), Pure Appl. Chem. 42, 431-477.

6. Baldo, B. A. \& Uhlenbruck, G. (1975), in: "Immunologic Phylogeny", Edited by W. H. Hildemann and A. A. Benedict. Adv. Exp. Med. Biol. 64, 3-11.

7. Eichmann, K., Uhlenbruck, G. \& Baldo, B. A. (1976). Immunochemistry 13, 1-6.
All these findings indicate that different precipitin reactions with different lectins may make a new, subtile classification of (serum) asialoglycoproteins possible on account of slightly differing carbohydrate units and their special sterical arrangement.
8. Uhlenbruck, G., Baldo, B. A. \& Steinhausen, G. (1975), Z. Immunitätsforsch. 150, 354-363.

9. Uhlenbruck, G., Steinhäusen, G., Gauwerky; Ch., Bäldo, B. A. \& Renwrantz, L. (1975), Biol. Zentralbl. 94 205-210.

10. Heide, K. \& Schwick, H. G. (1973), Angew. Chem. 85, $803-815$.

11. Uhlenbruck, G., Steinhausen, G. \& Baldo, B. A. (1975), Galactane und Anti-Galactane, Verlag Josef Stippak, Aachen.

12. Baldo, B. A., Turner, K. J. \& Uhlenbruck, G. (1976), Experientia 32, 641-644.

13. Müiler, H. E. (1974), Behring Inst. Mitt. 55, 34-56.

14. Watkins, W. M. \& Morgan, W. T. J. (1956), Nature (London) 178, 1289-1290.

Prof. Dr. med. G. Uhlenbruck Abt. exper. Innere Medizin

Kerpener Straße 15

D-5000 Kộln 41 